\title{
Pengembangan Destinasi Pariwisata Halal Pada Era Otonomi Luas di Provinsi Nusa Tenggara Barat
}

\author{
Abdul Kadir Jaelani \\ UIN Sunan Kalijaga, zaelanialan@ymail.com
}

\begin{abstract}
ABSTRAK
Penelitian ini bertujuan untuk mengetahui dan menganalisis latar belakang lahirnya pengembangan Pariwisata Halal di Provinsi Nusa Tenggara Barat dan kendala yang dialami dalam melaksanakan Perda Pariwisata Halal serta upaya yang dilakukan oleh Pemda tersebut. Hasil penelitian menunjukkan bahwa: Pertama, latar belakang lahirnya Perda tentang Pariwisata Halal di Provinsi Nusa Tenggara Barat berlandaskan pada tiga hal yaitu, pertama, landasan filosofisnya adalah pembangungan di bidang ekonomi dalam rangka mendukung terwujudnya percepatan kesejahteraan masyarakat, pemerataan kesempatan berusaha, memperoleh manfaat dan mampu menghadapi tantangan perubahan kehidupan dengan tetap memperhatikan sistem nilai budaya yang berlaku di masyarakat sesuai dengan nilai-nilai luhur pancasila. Kedua, landasan sosiologis pengembangan Pariwisata halal adalah aspek demografis dan geografis Provinsi Nusa Tenggara Barat sangat menunjang pelaksanaan pariwisata. Ketiga, landasan yuridis pengembangan Pariwisata halal adalah atribusi dan delegasi dari Pasal 18 ayat (6) UUD 1945, Pasal 9 UU No. 10 Tahun 2009 tentang Kepariwisataan, Pasal 12 ayat (3) hurup b dan Pasal 236 UU No, 23 Tahun 2014 tentang Pemerintahan Daerah dan Pasal 5 Permenparkreat No. 2 Tahun 2014 tentang Pedoman Penyelenggaraan Usaha Hotel Syari'ah.
\end{abstract}

Kata Kunci: Pariwisata Halal, Otonomi Daerah dan Nusa Tenggara Barat.

\begin{abstract}
This study aims to determine and analyze the background of the development of Halal Tourism in West Nusa Tenggara Province and the obstacles experienced in implementing the Halal Tourism Law and the efforts made by the local government. The results showed that: First, the background of the birth on Halal Tourism in West Nusa Tenggara first, the philosophical foundation is the development in the economic field in order to support the realization of the acceleration of the welfare of the people, the equality of business opportunities, the benefits and able to face the challenges of life change while maintaining the cultural value system prevailing in the community in accordance with the noble values of Pancasila. Second, sociological foundation of the birth on Halal Tourism is the demographic and geographical aspect of West Nusa Tenggara Province is very supportive of tourism implementation. Third, the legal basis on Halal Tourism is the attribution and delegation of Article 18 paragraphs (6) of the 1945 Constitution, Article 9 of Law no. 10 of 2009 on Tourism, Article 12 paragraphs (3) letters b and Article 236 of Law No. 23 of 2014 on Regional Government and Article 5 Permenparkreat No. 2 Year 2014 concerning Guideline for Sharia Business Operations.
\end{abstract}

Keywords: Halal Tourism, Regional autonomy and Nusa Tenggara Barat.

Naskah Masuk : 14 Maret 2018

Naskah Direvisi: 15 Maret 2018

Naskah Diterima : 9 April 2018

ISSN: 2355-6587, e-ISSN: 2528-2220

http://ejournal.bsi.ac.id/ejurnal/index.php/jp 
PENDAHULUAN

Otonomi daerah berfungsi untuk menciptakan keanekaragaman penyelenggaraan pemerintahan, sesuai dengan kondisi dan potensi masyarakat serta mengakomodasi keanekaragaman masyarakat, sehingga terwujud variasi struktur politik untuk menyalurkan aspirasi masyarakat. (Jeddawi, 2008) Pasal 1 ayat (6) Undang-Undang Nomor 23 Tahun 2014 tentang Pemerintahan Daerah menyebutkan bahwa otonomi daerah adalah hak, wewenang, dan kewajiban daerah otonom untuk mengatur dan mengurus sendiri urusan pemerintahan dan kepentingan masyarakat setempat dalam sistem Negara Kesatuan Republik Indonesia.

Pada pengertian lain, Samsul Wahidin memandang bahwa otonomi daerah sebagai suatu hak untuk mengatur dan memerintah daerah sendiri. Hak tersebut sumbernya dari desentralisasi, dekonsentrasi dan tugas pembantuan yang dilimpahkan oleh pemerintah pusat sebagai refleksi komitmen bersama yang harus senantiasa dijadikan sebagai landasan utama pelaksanaan pemerintahan. (Wahidin, 2013). Desentralisasi adalah penyerahan urusan pemerintahan oleh Pemerintah Pusat kepada daerah otonom berdasarkan asas otonomi. Adapun desentralisasi bidang kepariwisataan adalah urusan pemerintahan konkuren yang menjadi kewenangan dalam urusan pemerintahan pilihan. Salah satu urusan pemerintahan pilihan tersebut meliputi penyerahan urusan pemerintah pusat ke daerah untuk menetukan sumber-sumber daya tarik wisata, kawasan strategis pariwisata, dan destinasi pariwisata. (Pasal 12 ayat (3) hurup b Undang-Undang 23 Tahun 2014 tentang Pemerintahan Daerah) Pariwisata Halal adalah kegiatan kunjungan wisata dengan destinasi dan industri pariwisata yang menyiapkan fasilitas produk, pelayanan, dan pengelolaan pariwisata yang memenuhi syari'ah. Pasal 5 Peraturan Daerah Provinsi Nusa Tenggara Barat Nomor 2 Tahun 2016 tentang Pariwisata Halal menyebutkan bahwa, ruang lingkup pengaturan pariwisata halal meliputi destinasi, pemasaran dan promosi, industri, kelembagaan, pembinaan dan pengawasan dan pembiayaan. Pasal tersebut, mewajibkan juga kepada industri pariwisata konvensional untuk menyediakan arah kiblat di kamar hotel, informasi masjid terdekat, tempat ibadah bagi wisatawan dan karyawan muslim, keterangan tentang produk halal/tidak halal, tempat berwudhu yang terpisah antara laki-laki dan perempuan, sarana pendukung untuk melaksanakan sholat, dan tempat yang terpisah antara laki-laki dan perempuan dan memudahkan untuk bersuci. Adapun industri pariwisata halal adalah usaha-usaha wisata yang menjual jasa dan produk kepariwisataan yang berpatokan pada prinsip-prinsip syari'ah sebagaimana yang ditetapkan oleh DSNMUI.

Pariwisata halal merupakan kegiatan kunjungan wisata dengan destinasi dan industri pariwisata yang memenuhi unsur syariah di Pulau Lombok dan Pulau Sumbawa Provinsi Nusa Tenggara Barat. Provinsi Nusa Tenggara Barat memiliki kekayaan alam dan budaya yang sangat bervariasi dan prospek bagi pengembangan kepariwisataan. Keberadaan geografis yang letaknya berdekatan dengan Bali sebagai barometer pariwisata Indonesia ini menciptakan dan memberikan keuntungan tersendiri dalam distribusi wisatawan mancanegara, karena Provinsi NTB dianggap menjadi daerah tujuan wisata alternatif setelah bali. (Bappenas, 2013). Hal ini dapat dilihat dari jumlah kunjungan wisatawan ke Provinsi Bali pada tahun 2016 sebanyak 4.904.175 orang, (Dinas Pariwisata Bali, 2017) sedangkan pada tahun 2016 Nusa Tenggara Barat sebanyak 3.094.437 orang. (Dinas Kebudayaan dan Pariwisata Provinsi Nusa Tenggara Barat, 2017).

Berdasarkan data kunjungan wisatawan lima tahun terakhir, perkembangan kunjungan wisatawan ke Nusa Tenggara Barat mengalami peningkatan yang signifikan dibandingkan dengan Provinsi 
Bali. Perkembangan kunjungan wisatawan dari tahun ke tahun, baik wisatawan mancanegara maupun wisatawan nusantara pada periode tahun 2012-2016, mengalami peningkatan rata-rata sebesar $29,84 \%$. Peningkatan data tersebut menurut Burhan Bungin disebabkan oleh brand yang dilihat wisatawan. Lebih jauh Burhan Bungin berpendapat bahwa brand akan merangsang terciptanya pembelian dan perbedaan kunjungan wisatawan di kedua Provinsi disebabkan karena brand di kedua Provinsi ini dikonstruksi secara berbeda sehingga memberi rangsangan yang berbeda pula kepada wisatawan yang mengunjunginya. (Bungin, 2015)

Peningkatan kunjungan wisatawan setiap tahunnya tentu membawa pengaruh terhadap peningkatan pendapatan daerah dari sektor pariwisata khususnya penerimaan dari pajak hotel, pajak lestoran, pajak hiburan, retribusi tempat rekreasi dan olahraga dan retribusi rumah potong hewan. Peningkatan tersebut tentunya berdampak positif terhadap penerimaan devisa dan pendapatan asli daerah Provinsi Nusa Tenggara Barat. Nusa Tenggara Barat adalah salah satu Provinsi yang mempunyai banyak destinasi alam dan pantai. (Ahyamudi, 2016).

Potensi pesona keindahan alam serta keunikan budaya yang dimiliki tersebut, bukan berarti permasalahan di bidang pariwisata dapat terselesaikan. Pemerataan pembangunan pariwisata belum terlaksana dengan baik seperti fasilitas dan pelayanan pemenuhan infrastruktur dasar, seperti air bersih, listrik, jalan, bandara, pelabuhan, atraksi, pengemasan wisata yang menarik dan promosi destinasi pariwisata masih sangat terbatas, padahal wisatawan mengharapkan adanya pelayanan ekstra yang memberikan kepuasan dalam tuntutan atraksi. Permintaan atraksi wisata harus dipenuhi dengan tindakan-tindakan yang menarik seperti objek-objek wisata, pertunjukan kesenian, hiburan, upacara adat yang diadakan oleh masyarakat setempat dan cindera mata

\section{KAJIAN LITERATUR}

\section{Tinjauan tentang Pariwisata Halal}

Perkembangan konsep wisata halal berawal dari adanya jenis wisata jiarah dan religi (pilgrims tourism/spiritual tourism). Dimana pada tahun 1967 telah dilaksanakan konferensi di Cordoba, Spanyol oleh World Tourism Organization (UNWTO) dengan judul "Tourism and Religions: A Contribution to the Dialogue of Cultures, Religions and Civilizations". Wisata jiarah meliputi aktivitas wisata yang didasarkan atas motivasi nilai religi tertentu seperti Hindu, Budha, Kristen, Islam, dan religi lainnya. Seiring waktu, fenomena wisata tersebut tidak hanya terbatas pada jenis wisata jiarah/religi tertentu, namun berkembang ke dalam bentuk nilai-nilai baru yang bersifat universal seperti kearifan lokal, memberi manfaat bagi masyarakat dan unsur pembelajaran. Dengan demikian bukanlah hal yang mustahil jika wisatawan muslim menjadi segmen baru yang sedang berkembang di arena pariwisata dunia.( Priyadi, 2016)

Pengembangan wisata halal pada dasarnya bukanlah wisata eksklusif karena wisatawan non-Muslim juga dapat menikmati pelayanan yang berdasarkan nilai-nilai kehalalan. Wisata halal bukan hanya meliputi keberadaan destinasi ziarah dan religi, melainkan pula mencakup ketersediaan fasilitas pendukung, seperti restoran dan hotel yang menyediakan makanan halal dan tempat shalat. Produk dan jasa wisata, serta tujuan wisata dalam pariwisata halal adalah sama seperti wisata umum. Contohnya adalah menyediakan tempat ibadah nyaman seperti yang dilakukan Thailand dan negara lainnya yang telah menerapkan konsep tersebut terlebih dahulu. Potensi wisata halal di Indonesia sangat besar dan bisa menjadi alternatif selain wisata konvensional, hanya saja branding dan pengemasannya masih belum memiliki konsep yang tepat. (Andriani, 2015).

Pariwisata halal merupakan usaha pengembangan, Kemenparekraf yang menggandeng Dewan Syariah Nasional

ISSN: 2355-6587, e-ISSN: 2528-2220 
(DSN), Majelis Ulama Indonesia (MUI) dan Lembaga Sertifikasi Usaha (LSU) Tahun 2014 untuk menyusun pedoman penyelenggaraan usaha hotel syariah melalui Peraturan Menteri Pariwisata dan Ekonomi Kreatif Nomor 2 Tahun 2014. Permen tersebut berisikan kriteria hotel syariah dengan kategori hilal 1 dan hilal 2 yang dinilai dari aspek produk, pelayanan, dan pengelolaan. Hilal 1 merupakan hotel syariah yang masih memiliki kelonggaran dalam aturan syariah, misalnya, dalam hotel ini setiap makanan dan restoran dipastikan halal, sedangkan dalam hotel hilal 2, segala hal yang tidak diperbolehkan dalam aturan syariah memang sudah diterapkan dalam hotel syariah.

\section{Desentralisasi Kepariwisataan di Era Otonomi Daerah.}

Sejalan dengan bergulirnya tuntutan reformasi di berbagai bidang, pengelolaan pariwisata dan daerah juga mengalami reformasi. Pemikiran tentang reformasi di bidang pariwisata sebenarnya sudah dimulai sejak awal tahun 90-an berkaitan dengan upaya untuk mendukung pelaksanaan desentralisasi daerah, mendayagunakan, melestarikan, dan meningkatkan mutu objek dan daya tarik wisata, serta meningkatkan pendapatan nasional dalam rangka meningkatkan kesejahteraan dan kemakmuran rakyat. (Basuki, 2015).

Menurut Pasal 2 Undang-Undang Nomor 10 Tahun 2009 tentang Kepariwisataan menyebutkan bahwa pembangunan kepariwisataan dilakukan berdasarkan asas manfaat, kekeluargaan, adil, merata, keseimbangan, kemandirian, kelestarian, partisipatif, berkelanjutan, demokratis, kesetaraan dan kesatuan yang diwujudkan melalui pelaksanaan rencana pembangunan kepariwisataan dengan memperhatikan keanekaragaman, keunikan dan kekhasan budaya dan alam, serta kebutuhan manusia untuk berwisata, yang telah didesentralisasikan dapat tercermin pada pelaksanaan fungsi pelayanan pemerintahan yang bersifat lokal.
Sebelum otonomi daerah dilaksanakan, fungsi pemerintahan yang bersifat lokal tersebut dikelola oleh Pemerintah Pusat. Hal ini cenderung tidak memberikan dampak yang relatif lebih besar sehingga pengelolaan destinasi di daerah menjadi kurang efisien. Melalui kebijakan otonomi daerah, Pemerintah juga inginmewujudkan keadilan horisontal dan vertikal serta membangun kepariwisataan dilakukan berdasarkan rencana induk pembangunan kepariwisataan yang terdiri atas rencana induk pembangunan kepariwisataan nasional, rencana induk pembangunan kepariwisataan provinsi dan rencana induk pembangunan kepariwisataan kabupaten/ kota. (Manan, 2002).

Desentralisasi bidang pariwisata adalah urusan pemerintahan konkuren yang menjadi kewenangan dalam urusan pemerintahan pilihan. Salah satu urusan pemerintahan pilihan tersebut meliputi penyerahan urusan pemerintah pusat ke daerah untuk menetukan sumber-sumber daya tarik wisata, kawasan strategis pariwisata, dan destinasi pariwisata. Secara konseptual desentralisasi pariwisata kewenangan antara pusat dan daerah ini mencakup empat hal pokok. Pertama, wewenang dan tugas daerah (expenditure assignment) dalam mengelola destinasi pariwisata. Kedua, wewenang daerah untuk memasarkan pariwisata. Ketiga, wewenang daerah untuk mengembangkan ekonomi kreatif melalui pemanfaatan dan perlindungan hak kekayaan intelektual. Keempat, wewenang daerah untuk mengembangkan sumber daya pariwisata dan ekonomi kreatif. (Nurbaningsih, 2011).

Dalam bidang destinasi pariwisata, Pemerintah Pusat mempunyai wewenang sebagai berikut, pertama, penetapan daya tarik wisata, kawasan strategis pariwisata, dan destinasi pariwisata. Kedua, pengelolaan daya tarik wisata nasional. Ketiga, pengelolaan kawasan strategis pariwisata nasional, keempat, pengelolaan destinasi pariwisata nasional dan penetapan tanda daftar usaha pariwisata lintas Daerah Provinsi. Adapun Pemerintah

ISSN: 2355-6587, e-ISSN: 2528-2220 
Daerah Provinsi dalam bidang destinasi pariwisata mempunyai wewenang pengelolaan daya tarik wisata provinsi, pengelolaan kawasan strategis pariwisata provinsi, pengelolaan destinasi pariwisata provinsi dan penetapan tanda daftar usaha pariwisata lintas Daerah kabupaten/kota dalam 1 (satu) Daerah Provinsi. Sedangkan Pemerintah Daerah Kabupaten/Kota dalam bidang destinasi pariwisata mempunyai wewenang mengelola daya tarik wisata kabupaten/kota, mengelola kawasan strategis pariwisata kabupaten/kota, mengelola destinasi pariwisata kabupaten/ kota dan menetapkan tanda daftar usaha pariwisata kabupaten/kota. (Zamboni, 2010).

\section{METODE PENELITIAN}

\section{Jenis dan Sifat Penelitian}

Jenis penelitian yang digunakan dalam menyusun penelitian ini adalah penelitian kombinasi antara penelitian hukum normatif dan penelitian hukum empiris. Penelitian hukum normatif lebih mengutamakan studi pustaka (library research) yaitu kegiatan pengumpulan data yang berasal dari berbagai literatur baik dari perpustakaan maupun tempat lain, (Arikumto, 1993) sedangkan penelitian hukum empiris yaitu penelitian yang diperoleh langsung dari lapangan (field research) yaitu dengan melakukan pengamatan dan wawancara yang mendalam (in depth interview) dengan para responden dan narasumber yang berkompeten dan terkait dengan masalah yang diteliti. Penelitian ini bersifat deskriptif, yakni penelitian yang bertujuan untuk mendata dan mengklasifikasi gejalagejala yang digambarkan oleh peneliti dengan sebanyak mungkin diusahakan mencapai kesempurnaan atas dasar bangunan permasalahan penelitian. (Sumardjono, 2014).

\section{Data Penelitian}

Penelitian ini menggunakan data primer dan data sekunder. Data primer merupakan data yang diperoleh langsung dari sumbernya yang berupa fakta-fakta empiris. Data primer diperoleh secara langsung dari lokasi penelitian yaitu dengan cara wawancara langsung terhadap narasumber dan responden yang berkompeten dan terkait dengan masalah yang diteliti. Lokasi penelitian dalam penelitian ini adalah di Provinsi Nusa Tenggara Barat. (Sumardjono, 2014). Dalam penelitian ini peneliti juga menetapkan berbagai narasumber dan responden. Penentuan responden dilakukan dengan menggunakan pertimbanganpertimbangan dan kriteria-kriteria tertentu dengan berbekal pengetahuan yang cukup tentang populasi responden. Penentuan responden berdasarkan kriteria-kriteria tertentu yang dipandang mempunyai hubungan yang erat dengan masalah yang diteliti dan sesuai dengan tujuan penelitian. Kriteria yang dimaksud antara lain dengan memperhatikan kinerja, jabatan, keterlibatan, peran responden dalam pengelolaan pariwisata, responden tinggal di Nusa Tenggara Barat atau wisatawan yang pernah datang ke Nusa Tenggara Barat. (Soekanto, 2010)

Data sekunder merupakan bahan hukum dalam penelitian yang diambil dari studi kepustakaan yang terdiri dari bahan hukum primer, bahan hukum sekunder dan bahan non hukum. Data Sekunder diperoleh dengan studi dokumentasi dan penelusuran literatur yang berkaitan dengan penelitian ini. Bahan hukum untuk memperoleh data sekunder terdiri dari bahan hukum primer, bahan hukum sekunder dan tersier. (Fajar dan Achmad, 2010).

\section{PEMBAHASAN \\ Latar Belakang Lahirnya Pariwisata Halal di Provinsi Nusa Tenggara Barat Landasan Filosofis \\ Pembangunan kepariwisataan halal sebagai salah satu sektor pembangunan yang mendukung pembangunan di bidang ekonomi diarahkan dalam rangka mendukung terwujudnya percepatan kesejahteraan masyarakat, pemerataan kesempatan berusaha, memperoleh manfaat dan mampu menghadapi tantangan perubahan kehidupan lokal, nasional dan global dengan tetap}


memperhatikan sistem nilai budaya yang berlaku di masyarakat sesuai dengan nilainilai luhur pancasila. (Wawancara dengan Narasumber atas nama Ruslan Turmudzi, Anggota DPRD Provinsi NTB, 2017) Sila Peratama dari Pancasila adalah Ketuhanan Yang Maha Esa, yang secara filosofis mempengaruhi masyarakat Nusa Tenggara Barat (NTB) dalam menyambut dan memperlakukan tourism (tamu) sesuai dengan konsep Islam yang tidak bertentangan dengan nilai-nilai dan etika yang hidup di masyarakat berhubungan dengan konsep halal dan haram. Prinsip halal bagi masyarakat NTB diartikan dibenarkan, sedangkan haram diartikan dilarang. Konsep halal dipandang sebagai hukum makanan apa saja yang boleh dikonsumsi oleh tourism (tamu) sesuai keyakinannya, konsuekensinya adalah perlindungan konsumen. (Wawancara dengan Narasumber atas nama Heriadi, Sekretaris LPPOOK MUI NTB, 2017).

Semua agama dan ajaran, khususnya Islam sangat mementingkan kebaikan dan kebersihan dalam semua aspek. Dari segi makanan dan barang, semua agama memerintahkan umatnya agar memakan dan menggunakan bahan-bahan yang baik, suci, dan bersih. Makanan merupakan tolok ukur dari segala cerminan penilaian awal yang bisa mempengaruhi berbagai bentuk perilaku seseorang. Makanan bagi umat Islam tidak sekedar sarana pemenuhan kebutuhan secara lahiriah, akan tetapi juga bagian dari kebutuhan spiritual yang mutlak dilindungi. Dengan demikian halal-haram bukanlah persoalan sederhana yang dapat diabaikan, melainkan masalah yang amat penting dan mendapat perhatian besar dalam ajaran agama Islam, karena masalah ini tidak hanya menyangkut hubungan antar sesama manusia, tetapi juga hubungan manusia dengan Allah SWT, seorang muslim tidak dibenarkan mengkonsumsi sesuatu makanan sebelum ia tahu benar akan kehalalannya. Mengkonsumsi yang haram atau yang belum diketahui kehalalannya akan berakibat buruk, baik di dunia maupun di akhirat. Masalah ini mengandung dimensi duniawi dan sekaligus ukhrawi. Kebersihan, kesucian dan baik atau buruk sesuatu pangan dan produk lainnya termasuk kosmetik dan obat yang digunakan orang Islam senantiasa terkait dengan hukum halal atau haram. Oleh karena itu, umat Islam perlu mengetahui informasi yang jelas tentang halal dan haram pangan dan produk lainnya seperti makanan, minuman, destinasi dan barang gunaan lain. (Wawancara dengan Narasumber atas nama H. Abdurrahman Kuling, Sekretaris MUI NTB, 2017).

Wisata halal sebagai model kegiatan yang baru dalam pembangunan di sektor kepariwisataan dapat mengakomodir kebutuhan wisatawan nusantara dan mancanegara yang beragama Islam khususnya dalam melaksanakan kegiatan ibadahnya ketika berada di suatu lokasi dan destinasi wisata yang ada. Hal ini merupakan suatu kebutuhan keagamaan yang asasi bagi ummat sesuai dengan agama yang dianutnya, sehingga dalam mereka berwisata pada suatu destinasi selalu tersedia dan ada kemudahan bagi mereka dalam memenuhi kebutuhan dalam pelaksanaan ibadah, selain itu, sertifikasi halal bagi makanan dan minuman yang disuguhkan kepada para wisatawan juga menjadi syarat terwujudnya wisata halal. (Wawancara dengan Narasumber atas nama Muzihir, Anggota Fraksi Partai Persatuan Pembangunan Dewan Perwakilan Rakyat Daerah Provinsi Nusa Tenggara Barat, 2017). Pemerintah Daerah Nusa Tenggara Barat berkewajiban untuk dapat menjamin agar berwisata sebagai hak setiap orang dapat ditegakkan sehingga mendukung tercapainya peningkatan harkat dan martabat manusia, peningkatan kesejahteraan, serta persahabatan antarbangsa dalam rangka mewujudkan perdamaian dunia. Dalam menghadapi perubahan global dan penguatan hak pribadi masyarakat untuk menikmati waktu luang dengan berwisata, perlu dilakukan pembangunan kepariwisataan yang bertumpu pada keanekaragaman, keunikan, dan kekhasan 
bangsa dengan tetap menempatkan kebhinekaan sebagai suatu yang hakiki dalam bingkai Negara Kesatuan Republik Indonesia. (Wawancara dengan Narasumber atas nama Siti Hadijah, Kasubbag Rancangan Peraturan Daerah Biro Hukum Provinsi Nusa Tenggara Barat, 2017).

\section{Landasan Sosiologis}

Lahirnya pariwisata halal tidak terlepas dari jumlah penduduk. Jumlah penduduk akan menjadi salah satu modal utama dalam pembangunan kepariwisataan halal di Nusa Tenggara Barat pada masa sekarang dan yang akan datang karena memiliki fungsi ganda, di samping sebagai aset sumber daya manusia, juga berfungsi sebagai sumber potensi wisatawan nusantara. Secara sosiologis, aspek kependudukan di Provinsi Nusa Tenggara Barat sangat menunjang pelaksanaan pariwisata halal karena dengan kondisi masyarakat yang relatif homogen baik dari sisi etnis maupun agama. (Jaelani, 2014).

Berdasarkan stastik tahun 2016 terlihat bahwa Provinsi Nusa Tenggara Barat dihuni oleh tiga suku dominan, yaitu Sasak, Bima, dan Sumbawa yang masingmasing masih memiliki beberapa sub etnis, serta beberapa etnis lain dalam jumlah yang lebih sedikit seperti misalnya Dompu, Bali, Jawa, Bugis, Donggo dan lainnya. Suku Sasak adalah penduduk asli Lombok yang mendiami lebih dari 2/3 Provinsi Nusa Tenggara Barat, terdapat juga suku Samawa dan Mbojo yang berasal dari Pulau Sumbawa, suku Bali yang sudah berada di Lombok sejak permulaan abad ke 15, dan sekelompok kecil keturunan Cina dan Arab yang diperkirakan telah mendiami pulau Lombok sejak ratusan tahun silam. Mayoritas penduduk Nusa Tenggara Barat, terutama suku Sasak, Samawa, dan Mbojo, beragama Islam, walaupun demikian, seni budaya masyarakat di daerah ini adalah musik dan tarian, lebih banyak dipengaruhi kebudayaan Hindu dari pada Islam. Jumlah penduduk Provinsi Nusa Tenggara Barat pada tahun 2016 tercatat sebanyak 3,2 juta jiwa atau $70 \%$ dari jumlah penduduk
Provinsi NTB, yang terbagi menjadi 1,5 juta laki-laki dan 1,7 juta perempuan, dari segi agama, homogenitas penduduk masyarakat Nusa Tenggara Barat mayoritas beragama Islam, dengan gambaran kehidupan yang Islami seakan terwujud dari banyaknya jumlah masjid yang berdiri di povinsi ini. (Badan Pusat Stastik, 2017).

Persebaran penduduk menurut jenis kelamin di Provinsi Nusa Tenggara Barat sangat mendukung pengembangan industri pariwisata halal, mengingat pengembangan industri pariwisata halal yang merupakan industri berbasis layanan hospitality sangat membutuhkan tersedianya tenaga kerja perempuan dan laki-laki. Saat ini, industri pariwisata di Nusa Tenggara Barat menyerap lebih banyak tenaga kerja perempuan dibandingkan tenaga kerja lakilaki, yang terlihat dari serapan tenaga kerja per-sektor di Nusa Tenggara Barat di mana proporsi tenaga kerja perempuan yang bekerja di sektor perdagangan, hotel dan restoran sebesar 28,86 \%, sementara tenaga kerja laki-laki hanya sebesar 12,30 $\%$. Selain didukung oleh aspek sosiologis, pariwisata halal juga sangat didukung oleh faktor geografis. (Jaelani, 2017).

Secara geografis, Nusa Tenggara Barat terletak pada segitiga emas destinasi pariwisata utama di Indonesia yakni Pulau Bali di sebelah barat, Tana Toraja dan Bunaken di sebelah utara, dan Pulau Komodo di sebelah timur. Nusa Tenggara Barat juga berada pada segitiga emas pelayaran lintas nasional dan internasional yakni Surabaya di sebelah barat, Makassar di utara dan Darwin Australia di timur. Posisi ini memberikan berkah kepada Provinsi Nusa Tenggara Barat karena tidak hanya strategis sebagai destinasi wisata tetapi juga tempat transit kapal-kapal layar dari Darwin. Nusa Tenggara Barat juga dilalui oleh garis wallace, yakni garis pemisah antara kelompok spesies flora dan fauna Benua Asia dan Australia. Akibatnya, Nusa Tenggara Barat memiliki spesies flora dan fauna yang unik, karena menjadi titik pertemuan pengaruh kedua benua tersebut. Posisi ini menjadikan Nusa 
Tenggara Barat tempat yang menarik untuk dikembangkan pariwisata halal.

\section{Landasan Yuridis}

Peraturan Daerah (Perda) merupakan peraturan terendah dalam sistem hierarki peraturan perundang-undangan, yang memiliki arti strategis dalam rangka memberi isi otonomi daerah. Perda dibentuk untuk melaksanakan segala hal yang menyangkut otonomi dan tugas pembantuan, dimaksudkan agar dapat terwujud kesejahteraan masyarakat karena pemerintah daerah yang lebih tahu kebutuhan terkait di daerah. Perda merupakan peraturan untuk melaksanakan aturan hukum di atasnya dan menampung kondisi khusus dari daerah yang bersangkutan. Kondisi khusus daerah yang dimaksud bukan sematamata karena adanya UU yang memberikan otonomi khusus. Klausula bahwa Perda mengatur kondisi khusus karena dianggap sebagai peraturan yang paling dekat dalam mengakomodasi nilai-nilai masyarakat di daerah. Nilai-nilai tesebut diidentifikasi sebagai kondisi khusus daerah. (Rimdan, 2012).

Sumber kekuasaan dalam pembentukan Perda tidak dapat dilepaskan dari pembagian kekuasaan untuk mengatur di dalam suatu negara. Kekuasaan mengatur dilakukan secara atributif dan delegatif. Kedua cara perolehan kekuasaan itu mempunyai ciri-ciri yang berbeda dalam pembentukan peraturan perundangundangan. Perolehan secara atributif akan menyebabkan terjadinya pembentukan kekuasaan karena kekuasaan itu berasal dari keadaan yang belum ada menjadi ada. Atribusi kewenangan pembentukan peraturan perundang-undangan yang dimaksud adalah pemberian kewenangan membentuk peraturan oleh grondwet (Undang-Undang Dasar) atau oleh Wet (Undang-Undang) kepada suatu lembaga negara atau lembaga pemerintahan baik di tingkat pusat maupun daerah. (Indrati, 2007).

Terkait dengan pengertian delegasi kewenangan dalam pembentukan peraturan perundang-undangan adalah pelimpahan kewenangan membentuk peraturan yang dilakukan oleh peraturan perundangundangan yang lebih tinggi kepada peraturan perundang-undangan yang lebih rendah. Ciri yang melekat dalam delegasi kewenangan pembentukan peraturan perundang-undangan adalah pendelegasian harus dilakukan oleh badan yang berwenang, pendelegasian menyebabkan hilangnya wewenang bagi delegant dalam jangka waktu yang telah ditentukan, delegataris (penerima delegasi wewenang) harus bertindak atas nama sendiri, dan oleh karen itu seorang delegataris bertanggung jawab secara eksternal terhadap segala pelaksanaan kekuasaan yang timbul dari pendelegasian kekuasaan itu dan sub delegasi hanya dapat dilakukan apabila ada persetujuan dari delegant. (Muchsan, 1988).

Peraturan Daerah Provinsi Nusa Tenggara Barat Nomor 2 Tahun 2016 merupakan atribusi dan delegasi dari Pasal 18 ayat (6) UUD 1945, Pasal 9 Undang-Undang Nomor 10 Tahun 2009 tentang Kepariwisataan, Pasal 12 ayat (3) hurup b dan Pasal 236 Undang-Undang Nomor 23 Tahun 2014 tentang Pemerintahan Daerah dan Pasal 5 Peraturan Menteri Pariwisata dan Ekonomi Kreatif Nomor 2 Tahun 2014 tentang Pedoman Penyelenggaraan Usaha Hotel Syari'ah. Pariwisata halal merupakan ciri khas kedaerahan (muatan lokal) di Nusa Tenggara Barat. Tekhnis Penyusunan Perda Pariwisata Halal melalui tiga tahap yaitu terencana, terpadu dan sistematis. Terencana merupakan skala waktu (jangka panjang, menengah dan pendek), dalam rangka menterjemahkan RPJPD, RPJMD, dan RKPD, sedangkan terpadu merupakan pelibatan berbagai instansi dan pemangku kepentingan agar dapat menampung berbagai aspirasi dan permasalahan yang berkembang dan sistematis yang merupakan disusun berdasarkan kajian yang dikaitkan secara substantif dengan peraturan perundangundangan lainnya dan yang lebih tinggi untuk menghindari komplikasi. (Setiadi, 2017). 
Kendala dan Upaya Pemerintah Provinsi Nusa Tenggara Barat dalam melaksanakan Pariwisata Halal

Upaya mengukuhkan peran dan posisi sektor pariwisata halal sebagai pilar strategis pembangunan kepariwisataan yang berdaya saing dan berkelanjutan di Nusa Tenggara Barat, tidak dapat dipungkiri masih dihadapkan pada sejumlah permasalahan dan kendala yang menuntut langkah dan upaya yang taktis dan terpadu dalam mengatasinya. Kendala dan upaya tersebut dapat dijabarkan sebagai berikut:

Pengaturan terhadap Industri dan Destinasi Pariwisata Halal

Peningkatan Pendapatan Asli Daerah (PAD) sektor pajak tidak diikuti ole peningkatan retribusi sektor tempat rekreasi dan olahraga, karena Pemerintahan Kota Mataram dan Kabupaten Lombok Timur belum menetapkan Perda Induk Pariwisata. Kewenangan Daerah dalam menetapkan Perda Induk Pariwisata seharusnya memperhatikan kriteria pungutan Daerah yang telah ditetapkan dalam PDRD.

Pasal 23 A UUD Tahun 1945, merupakan dasar pemungutan pajak yang berbunyi pajak dan pungutan lain yang bersifat memaksa untuk keperluan negara diatur dengan undang-undang. Ketentuan tersebut menegaskan bahwa retribusi harus berdasarkan undang-undang karena memberikan imbalan yang secara langsung dapat ditunjuk. Peralihan kekayaan yang tanpa imbalan hanya dapat berupa, perampokan, pencurian, perampasan atau pemberian secara sukarela, oleh karenanya semua pungutan pajak dan pungutan lainnya harus terlebih dahulu mendapatkan perstujuan dari rakyat melalui Dewan Perwakilan Rakyat. Falsafah ini sama dengan falsafah pajak di Inggris yaitu no taxation without representation dan Amerika "taxation without representation is robberry. ( Soebechi, 2012).

Salah satu sumber pendapatan daerah adalah pengenaan pungutan daerah berupa pajak daerah dan retribusi daerah yang ditetapkan dengan peraturan daerah kemudian diformulasikan sebagai komponen pendapatan asli daerah (PAD). Melalui PAD, pemerintah daerah diharapkan mampu mendanai penyelenggaraan pemerintahan daerah dan pembangunan daerah, yang pada akhirnya dapat mewujudkan pemerataan kesejahteraan masyarakat lokal. Daerah dituntut untuk lebih mampu meningkatkan PAD-nya dalam rangka melaksanakan desentralisasi fiskal, serta mengatur dan mengurus rumah tangganya sendiri demi tercapinya tujuan pemerataan kesejahteraan masyarakat sebagaimana yang diharapkan.

Desentalisasi fiskal merupakan suatu proses distribusi anggaran dari tingkat pemerintahan yang lebih tinggi ke pemerintahan yang lebih rendah untuk mendukung fungsi atau tugas pemerintah yang dilimpahkan. Prinsip dasarnya adalah money follow functions, artinya penyerahan atau pelimpahan wewenang pemerintah membawa konsekuensi anggaran yang diperlukan untuk melaksanakan kewenangan tersebut. ( Soebechi, 2012).

Pemberdayaan Organisasi Masyarakat dalam Mewujudkan Ketertiban dan Keamanan Wisatawan Berkunjung ke Destinasi

Kriminalitas di Kabupaten Lombok Timur dan Kota Mataram dan Lombok pada umumnya merupakan persoalan krusial. Kota Mataram dan Kabupaten Lombok Timur menampilkan religiusitas (pariwisata halal) sekaligus kriminalitas. Religiusitas (pariwisata halal) ditunjukkan dengan julukan sebagai daerah dengan seribu masjid, dan pada saat yang bersamaan angka kriminalitas di sana pernah sampai pada tahap terang-terangan. Apabila melakukan tindak kriminal tidak lagi dibuat dengan sembunyi-sembunyi tetapi dilakukan secara terbuka dan menyatakan niatnya di awal. Munculnya "kampung maling" di beberapa tempat menjadi gambaran lain yang menunjukkan betapa persoalan keamanan dan ketertiban wisatawan menjadi persoalan serius di daerah ini. (Maladi, 2007). 
Menurut Zubain \& Murdiono, selaku ketua pemuda kreatif Kecamatan Jerowaru menyatakan bahwa, tingginya angka kriminalitas disebabkan oleh beberapa hal, pertama, kemiskinan merupakan salah satu faktor yang secara psikiologis mengarahkan masyarakat untuk menghalalkan segala cara dalam pemenuhan kebutuhan hidup. Secara umum angka kemiskinan tidak kurang dari $50 \%$. Kemiskinan sendiri muncul dari bekerjanya beberapa faktor diantaranya kondisi alam yang kering dan keterlibatan masyarakat sekitar obyek destinasi sangat terbatas. Pada saat yang bersamaan, keterampilan, keahlian dan skill penduduk sekitar sangat terbatas tentang pariwisata, bukan hanya dalam variasi jumlah tetapi sekaligus kualitas dari skill penduduk itu sendiri. (Jaelani, 2017).

Kedua, prilaku kriminalitas, seperti maling, juga dikukuhkan dengan budaya. Saharudin selaku Dewan Takepan Masyarakat Adat Sasak menyatakan bahwa, ritual mencuri mempelai wanita difasiltasi oleh adat sebagai bagian dari mempertahankan martabat seseorang. Bahkan, lebih lanjut ditunjukkan olehnya bahwa para pencuri ulung akan diangkat sebagai datu maling/raja pencuri. Ketiga, keterbatasan aparat kepolisian menjadi persoalan lain yang mendorong kriminalitas di Kota Mataram dan Kabupaten Lombok Timur. Kelangkaan aparat kepolisian bukan hanya persoalan Kota Mataram dan Kabupaten Lombok Timur semata, tetapi ia menjadi semakin problematik ketika kriminalitasnya tinggi. Berbagai kriminalitas yang dialami oleh wisatawan yang tidak mampu ditangani secara baik melahirkan efek sendiri bagi perkembangan pariwisata halal. Karenanya, kriminalitas berkembang dengan baik sementara itu ketersediaan aparat sangat terbatas.

Di tengah kriminalitas yang tinggi dan aparat keamanan tidak mampu berbuat banyak kemudian melahirkan salah satunya adalah munculnya pam-swakarsa. Beberapa pam-swakarsa yang muncul dan memiliki basis yang kuat di Pulau Lombok adalah Elang Merah dan Amphibi. Institusi keamanan tersebut berjejaring dan bekerja sampai pada tingkat desa. Mereka bahkan memiliki sarana keamanan yang relatif lengkap dan mengikuti pola kerja yang lebih intensif dalam mengkonsolidasikan keamanan di daerah. Untuk saat ini Pemerintah Daerah Provinsi Nusa Tenggara Barat dan Elang Merah-Amphibi melakukan kerjasama dalam menciptakan keamanan di Nusa Tenggara Barat.

\section{PENUTUP}

Berdasarkan hasil penelitian dan pembahasan pada sebelumnya, maka dapat ditarik kesimpulan sebagai berikut:

Latar belakang lahirnya Pariwisata Halal di Provinsi Nusa Tenggara Barat berlandaskan pada tiga hal yaitu, landasan yuridis, filosofis dan sosiologis. Landasan yuridis lahirnya Perda Provinsi Nusa Tenggara Barat Nomor 2 Tahun 2016 merupakan atribusi dan delegasi dari Pasal 18 ayat (6) UUD 1945, Pasal 9 UndangUndang Nomor 10 Tahun 2009 tentang Kepariwisataan, Pasal 12 ayat (3) hurup b dan Pasal 236 Undang-Undang Nomor 23 Tahun 2014 tentang Pemerintahan Daerah dan Pasal 5 Peraturan Menteri Pariwisata dan Ekonomi Kreatif Nomor 2 Tahun 2014 tentang Pedoman Penyelenggaraan Usaha Hotel Syari'ah. Sedangkan landasan filosofisnya adalah pembangungan di bidang ekonomi dalam rangka mendukung terwujudnya percepatan kesejahteraan masyarakat, pemerataan kesempatan berusaha, memperoleh manfaat dan mampu menghadapi tantangan perubahan kehidupan dengan tetap memperhatikan sistem nilai budaya yang berlaku di masyarakat sesuai dengan nilai-nilai luhur pancasila serta mengakomodir kebutuhan wisatawan dalam melaksanakan kegiatan ibadahnya ketika berada di suatu lokasi destinasi, karena ibadah adalah kebutuhan asasi bagi ummat sesuai dengan agama yang dianutnya, menjunjung nilai-nilai kebaikan dan kebersihan sesuai dengan ajaran Islam. Adapun landasan sosiologis lahirnya Perda tentang Pariwisata halal adalah aspek kependudukan dan geografis

ISSN: 2355-6587, e-ISSN: 2528-2220

http://ejournal.bsi.ac.id/ejurnal/index.php/jp 
di Provinsi Nusa Tenggara Barat sangat menunjang pelaksanaan pariwisata halal karena kondisi masyarakat yang relatif homogen baik dari sisi etnis maupun agama, selain faktor demografi, pariwisata halal juga sangat didukung oleh faktor geografis. Secara geografis, Nusa Tenggara Barat terletak pada segitiga emas destinasi pariwisata utama di Indonesia, segitiga emas pelayaran lintas nasional dan internasional dan dilalui oleh garis wallace, yakni garis pemisah antara kelompok spesies flora dan fauna Benua Asia dan Australia.

Adapun kendala dan upaya Pemerintah Provinsi Nusa Tenggara Barat dalam melaksanakan Perda Pariwisata Halal adalah sebagai berikut, pertama, pengaturan terhadap industri dan destinasi pariwisata halal, terdapat beberapa masalah utama yang dihadapi dan menjadi kendala bagi tumbuhnya industri pariwisata halal, antara lain pengaturan terhadap pemungutan retribusi dan konflik tanak pecatu di obyek destinasi pariwisata, untuk mengatasi permasalahan tersebut, Pemerintah telah melalukan penyuluhan, monitoring dan sosialisasi kepada masyarakat, melakukan inventarisasi aset daerah ke masing-masing SKPD dan melakukan pendataan aset Pemerintah Daerah bekerja sama dengan Badan Pertanahan Nasional untuk melakukan sertifikasi tanah Pemda yang belum mempunyai sertifikat. Kedua, terbatasnya anggaran infrastruktur transportasi ke wilayah destinasi, untuk mengatasi masalah tersebut, Pemerintah Daerah mulai mengaspal jalan-jalan strategis menuju destinasi pariwisata dan menyediakan angkutan umum antar kecamatan yang dikordinir oleh Dinas Perhubungan. Ketiga, pemberdayaan organisasi masyarakat dalam mewujudkan ketertiban dan keamanan wisatawan berkunjung ke destinasi, untuk mengatasi permasalahan tersebut, Pemerintah Daerah Provinsi Nusa Tenggara Barat dan Elang Merah-Amphibi melakukan kerjasama dalam menciptakan keamanan di Nusa Tenggara Barat.

\section{REFERENSI}

Andriani, Dini, (2015). Kajian Pengembangan Pariwisata Syari'ah Indonesia. Jakarta. Asisten Deputi Penelitian dan Pengembangan Kebijakan Kepariwisataan Deputi Bidang Pengembangan Kelembagaan Kepariwisataan Kementerian Pariwisata.

Arikumto, Suharsimi. (1993). Prosedur Penelitian Suatu Pendekatan. Rineka Cipta. Jakarta.

Pusat Badan Stastik. (2017). Nusa Tenggara Barat dalam Angka. Mataram. Badan Pusat Stastik.

Bappenas. (2013). Koridor Ekonomi BaliNusa Tenggara Barat. Jakarta. Bappenas.

Basuki, Udiyo (2015). "Amandemen Kelima Undang-Undang Dasar 1945 sebagai Amanat Reformasi dan Demokrasi”. Jurnal Panggung Hukum Perhimpunan Mahasiswa Hukum Indonesia. Vol.1 No.1 Januari 2015.

Bungin, Burhan (2015). Komunikasi Pariwisata: Pemasaran dan Brand Destinasi. Kencana. Jakarta.

Dinas Kebudayaan dan Pariwisata Provinsi Nusa Tenggara Barat. (2017). Laporan Kinerja Dinas Kebudayaan dan Pariwisata Provinsi Nusa Tenggara Barat. Dispar. Mataram.

Indrati, Maria Farida. (2007). Ilmu Perundang-Undangan: Proses dan Teknik Penyusunannya. Kanisius. Yogyakarta.

Jaelani, Abdul Kadir. (2015). Percikan Pemikiran Mahasiswa Kota Pelajar untuk Pulau Seribu Masjid. GEMMA NW Yogyakarta. Yogyakarta. 
Jaelani, Abdul Kadir. (2017). "Implikasi Berlakunya Peraturan Daerah Provinsi Nusa Tenggara Barat Nomor 2 Tahun 2016 Tentang Pariwisata Halal di Kota Mataram dan Kabupaten Lombok Timur". Tesis. Program Studi Magister Hukum Konsentrasi Hukum Kenegaraan Universitas Gadjah Mada. Yogyakarta.

Jeddawi, Murtir. (2008). Implementasi Kebijakan Otonomi Daerah (Analisis Kewenangan, Kelembagaan, Manajemen Kepegawaian, dan Peraturan Daerah). Total Media. Yogyakarta.

Maladi, Yanis. (2007). Gumi Sasak dalam Sejarah. Yayasan Budaya Sasak Lestari. Selong.

Manan, Bagir. (2002). Menyongsong Fajar Otonomi Daerah. PSH FH UII. Yogyakarta.

Muchsan. (1981). Seri Hukum Administrasi Negara: Peradilan Administrasi Negara. Liberty. Yogyakarta.

Nurbaningsih, Enny. (2011). "Aktualisasi Pengaturan Wewenang Mengatur Urusan Daerah Dalam Peraturan Daerah (Studi Periode Era Otonomi Seluas-Luasnya)", Disertasi, Program Doktor Pascasarjana, Fakultas Hukum Universitas Gadjah Mada. Yogyakarta.

Priyadi, Unggul. (2016). Pariwisata Syari'ah Prospek dan Perkembangan, UPP Sekolah Tinggi Ilmu Manajemen. Yogyakarta.

Rimdan. (2012). Kekuasaan Kehakiman Pasca Amandemen Konstitusi. Kencana. Jakarta.

Setiadi, Wicipto. (2017). "Dinamika Proses Pembentukan Peraturan Perundang-Undangan”, Bahan Kuliah
Hukum Peraturan PerundangUndangan. Program Studi Magister Hukum Konsentrasi Hukum Kenegaraan Universitas Gadjah Mada. Yogyakarta.

Soebechi, Imam. (2012). Judicial Review Perda Pajak dan Retribusi Daerah. Sinar Grafika. Jakarta.

Soekanto, Soerjono. (1986). Pengantar Penelitian Hukum. UI Press. Jakarta.

Sumardjono, Maria SW. (2014). "Metodologi Penelitian Ilmu Hukum". Bahan Kuliah. Magister Hukum Fakultas Hukum Universitas Gadjah Mada. Yogyakarta.

Wahidin, Samsul (2013). Hukum Pemerintahan Daerah: Pendulum Otonomi Daerah dari Masa ke Masa. Pustaka Pelajar. Yogyakarta.

Zamboni, Moura. (2010). The Social in Social Law-An Analysis of a Concept in Disguise. Stockholm Institute. Scandianvian Law.

\section{BIODATA PENULIS}

Abdul Kadir Jaelani, S.H. M.H. lahir di Wakan Kecamatan Jerowaru Kabupaten Lombok Timur Provinsi Nusa Tenggara Barat, Tanggal 4 Agustus 1991. Menyelesaikan Sekolah Dasar di SDN 06 SUKARAJA Lulus Tahun 2004, Kemudian MTs Pondok Pesantren Nurul Muttaqin NW Wakan Lulus Tahun 2007. Pada Tahun 2007 melanjutkan ke MA Pondok Pesantren Nurul Haramain NW Putra Narmada Lulus Tahun 2011 dan pada Tahun 2015 berhasi menyelesaikan Program Studi Ilmu Hukum Konsentrasi Hukum Tata Negara Fakultas Syari'ah dan Hukum UIN Sunan Kalijaga dengan predikat lulusan terbaik dan tercepat. Pada tahun 2016 berhasil melanjutkan studi magister ke Magister Hukum Program Pascasarjana Fakultas Hukum Universitas Gadjah Mada melalui Beasiswa LPDP. 